\title{
General Practitioner's Level of Survey on Trauma Cases in Dustira Level II Hospital
}

\author{
Andri Anugerah Kusuma, Rizki Bunawan*, Alexander Siagian \\ Faculty of Medicine \\ Jenderal Achmad Yani University \\ Cimahi, Indonesia \\ *dr.rizkibunawan@gmail.com
}

\begin{abstract}
The high incidence of trauma caused by traffic accidents and other causes resulting in the high mortality of trauma. A general practitioner (GP)'s primary survey knowledge and management could minimalized the risk of the death. RS Tingkat II Dustira has an emergency department so the GPs ought to have knowledge in primary survey. This study used observational descriptive method using primary data collected from the questionnaire filled by 39 GPs in RS Tingkat II Dustira. The data was analyzed univariately. The respondents' length of work mostly were 1-10 years (26 respondents). $40 \%$ of the GPs who went through ATLS training before had a good knowledge and $72 \%$ of the GPs who didn't go through ATLS had a good knowledge. The GP's who had a good knowledge about primary survey's first component, airway, were $27 \%$ GPs, in the breathing component were $13 \%$, the circulation component was 49\%, disability component were $92 \%$, and $87 \%$ respondents in exposure component. This is an interesting study as an addition to RS Tingkat II Dustira to refresh the knowledge for the GPs. The levels of knowledge in primary survey are better descriptively in the GPs which underwent the Non-ATLS training but with good experience because it was influenced by the length of work in the emergency department.
\end{abstract}

Keywords-general practitioner, levels of knowledge, primary survey

\section{INTRODUCTION}

\section{A. Background}

Trauma is physical and psychological injury, violence that results in injury, can cause death if not handled properly [1]. One of the causes of this death is not getting optimal treatment during the trip to the hospital. WHO research in 2013 states that trauma has developed into a health problem that consumes the most funds and is the fourth contributor of deaths in the world $[1,2]$.

The most common cause of death from trauma is traffic accidents. As the use vehicles are increasing, in recent years an increase in number of traffic accidents happened and caused estimated 20-50 million people suffered severe head injuries and 1 million people per year end in death. World Health Organization (WHO) based on the report Global Status on
Road Safety in 2013, expressed the greatest prevalence of traffic accidents occurred in low- and middle-income countries. As many as $62 \%$ of reported traffic fatalities occur in developing countries $[2,3]$.

Based on official data from WHO Southeast Asia Regional in 2013, in West Java area, deaths due to traffic accidents occurred 4 people per hour, while in Cimahi in 2013 there were 500 traffic accidents and about 35\% ended in death. World Health Organization (WHO) also expressed traffic accidents is the leading cause of death of children in the world among 1024 years while research in Indonesia shows about $78 \%$ of deaths from accidents occurs at age 18-55 years. This range is the productive age which will certainly affect the welfare of society and the country [3-7].

There are also many other causes of trauma apart from traffic accidents. The causes of trauma vary from thermal trauma, drowning, gunshot wounds, falls, and others with various organ or tissue damage. It needs serious handling in preventing the increasing mortality that occurs due to trauma $[4,8]$.

The assessment and management of trauma victims must be carried out quickly because time is valuable in preventing the victim from experiencing the worst condition, which is death. The initial management of trauma victims is organized in a process known as the initial assessment, which aims to prioritize victims who needs prior assistance and determine any circumstances that directly threaten the victim's life. Initial assessment is arranged so that time can be used effectively and efficiently with steps including preparation, triage, primary survey (airway, breathing, circulation, disability, exposure), resuscitation, addition to primary survey and resuscitation, consideration of possible referrals, secondary survey (head to toe examination and history), addition to secondary surveys, monitoring with ongoing re-evaluation, and definitive treatment $[4,8]$.

Along with the increasing number of trauma cases, health workers should know and be able to carry out primary surveys when trauma cases occur, which often occur in everyday life. A primary survey as part of the initial assessment 
is carried out to immediately identify life-threatening situations that can still be handled immediately. Doctors, as part of the health workforce, together with nurses have a very important role in handling trauma victims $[8,9]$.

In the past, many doctors did not understand how a good primary survey was. January 1980, the American College of Surgeon made a training program, namely Advanced Trauma Life Support for Doctors (ATLS) with the aim that doctors can overcome trauma cases in the first hour of trauma management, both in remote rural areas and in sophisticated Trauma Centers. The ATLS becomes an internationally recognized emergency training for physicians and a guideline for emergency training. For more than a quarter of a century, the American College of Surgeon Committee has taught ATLS to more than 1 million doctors in more than 50 countries. ATLS has become the basis of care for injured patients. As time goes on, the number of doctors taking ATLS in increasing and to prevent an increase in the death rate it should increase [3,4].

Dustira Hospital is a type B hospital located in Cimahi city. In accordance with the Decree of the Minister of Health no 340 on Classification of Hospitals, it has to provide 24-hour emergency care with health professionals who have the ability for initial emergency inspection, perform resuscitation and standardized stabilization. In previous research obtained that every day there were about 80 new cases entering the emergency room with $30-40 \%$ of these cases being trauma cases. The high incidence of trauma that enters the Emergency Room of the Dustira Hospital every day is accompanied by a prediction of the possibility of an increase in the number of traumas that result in death from year to year requiring general practitioners of Dustira Hospital to be proficient in primary survey management $[10,11]$.

Study regarding the description of primary survey knowledge on nurses regarding trauma cases in the Emergency Room at Dustira Hospital, resulted in 50\% had a high level of knowledge. There hasn't been a study on general practitioners in Dustira Hospital about the level of knowledge of general practitioners on primary survey in trauma cases. Based on this background, the researchers were interested in conducting research on general practitioner knowledge of primary survey on trauma cases at the Dustira Hospital [11].

\section{LITERATURE REVIEW}

\section{A. Definition and Levels of Knowledge}

Knowledge is the result of human sensing of objects through the senses, especially by the sense of hearing and sight and is an important domain for the formation of behavior. Knowledge also includes everything that is seen, heard, tasted, touched and present in individual consciousness, spontaneously, subjective, and / or intuitively. The time spent from sensing to producing knowledge is greatly influenced by the intensity of attention and perception of the object. Someone's knowledge of the object has different kinds of intensity. Broadly speaking, knowledge is divided into six levels, namely knowing, understanding, application, analysis, synthesis, evaluation $[12,13]$.

- Knowing: Knowing can be interpreted as a recall of preexisting memory after observing an object. What is included in the level of knowing in knowledge is recalling all the information or stimuli that have been received. Measurement of the level of knowing can be done for example with commands to say, describe, or define [12-15].

- Understand: Understanding is defined as a person's ability to understand things that have been studied and to be able to properly and correctly explain or interpret these things. The results that are reflected in individuals who are already at this level are that these individuals can explain, cite examples, conclude, and think about the possibilities that will occur related to what is understood [12-15].

- Application: Application is the ability that comes out of individuals to use stimuli that have been received in real reality. Individuals who have reached the application level will apply and use the principles, theories, or methods that have been learned and absorbed in their previous experience [12-15].

- Analysis: Analysis is defined as a person's ability to associate an idea with an idea that is still interconnected. The ability that can be measured in an individual for this level of knowledge is the use of verbs for example to describe, separate, or differentiate [12$15]$.

- Synthesis: Synthesis is defined as the individual's ability to relate things that have been learned, but are separate, into a whole new form or can make new formulations from existing formulations or theories. The individual's ability in the level of synthetic knowledge can be measured by the individual's ability to summarize, compile, or adapt something to existing theories or formulations [12-15].

- Evaluation: Evaluation is defined as an individual's ability to make an assessment of the material or object being studied. The assessment can be based on assessment criteria made by individuals or using preexisting criteria or formulations [12-15].

1) Factors affecting knowledge: The knowledge gained from a set of interconnected information systematically and quite different beliefs, superstition, or missed information. Knowledge is influenced by two factors, namely internal and external factors. The internal factors consist of education, experience, and age. External factors consist of economy, environment, information, culture [14].

Education is an effort to develop personality and abilities inside and outside school and lasts a lifetime. Education is a learning process, the higher the education a person has, the easier it is to receive information. Education is a higher process 
that will automatically be directly proportional to the knowledge they have, so that general practitioners who often attend emergency training will increase their knowledge $[15,16]$.

Experiences are things that have been experienced by someone or by others. Therefore, experience can come from oneself or from others, and can expand the knowledge of the individual. Experience is associated with length of work. Individuals who have longer working period will automatically form adequate experience and create effective patterns and can solve various problems based on their experience, skills and knowledge. Likewise, a general practitioner who has more experience in handling emergency victims will be more skilled $[15,16]$

Culture is a tradition or habit that is carried out by society without going through reasoning in assessing good or bad things. Culture is obtained by going down and down and greatly influences individual attitudes in accepting new information. Cultural development is a sign that the community has undergone a change in thought processes [15].

Information certainly plays a role in influencing individual knowledge. Information is closely related to the facilities or technology available. The more complete and sophisticated the technology available as a source of information, the more individual knowledge will be. Examples of facilities or technology as information are newspapers, internet, cell phones, television, and others [15].

The environment is everything that is around the individual, whether it is physical, biological, or social. The environment affects the process of entering knowledge into the individuals who are in that environment. The difference in environmental impact on knowledge, for example, can be seen from the knowledge of urban communities which is more open when compared to the knowledge of rural communities. The economic status or financial situation of an individual can also affect the knowledge of that individual. This is because the economic status or financial situation is related to an individual's ability to have information sources $[15,16]$.

Age affects a person's perceptive power and mindset. Increasing age will lead to increased comprehension and mindset, so that the knowledge gained is getting better, but in elderly individuals there is a decline in their perceptive power and mindset which causes the knowledge gained to decrease $[15,16]$.

Knowledge can be obtained in 2 ways, namely the traditional way and the modern way. This traditional way consists of the trial and error method, the way of power and authority, based on personal experience and through the way of thinking. Nowadays it's more logical and scientific to use the modern way. The modern method is called the scientific research method. Modern methods can be done by interview or questionnaire that asks about the content of the material to be measured from the research subject or respondent [12].
The level of knowledge can be categorized based on value, namely good knowledge with a knowledge value of more than $75 \%$, sufficient knowledge with a knowledge value of 60 $75 \%$, while less knowledge has a value of knowledge less than $60 \%$ [12].

\section{B. Primary Survey}

The primary survey is one part of the initial assessment, which is carried out to immediately identify life-threatening trauma that can still be treated immediately. The Advanced Trauma Life Support (ATLS) course from the American College if the Surgeons Committee on Trauma provides guidance in primary survey actions in the order of airway maintenance with spine protection, breathing and ventilation, circulation with hemorrhage control, disability and neurologic status, and exposure or environment control and completely undress the patient but prevent hypothermia [4].

1) Airway with cervical spine protection: Airway and breathing are top priorities in the management of trauma victims. This is because the breathing process will not go well without an adequate airway. A hypoxic state will cause the inability of the blood to properly supply oxygen to the brain and other vital organs, which can lead to death. This airway examination includes examining the presence of airway obstruction caused by a foreign body (corpus alienum), facial bone fracture, maxillary fracture, mandibular fracture, laryngeal fracture, or tracheal fracture $[4,17]$. The anatomy of respiration can be seen in Figure 1.

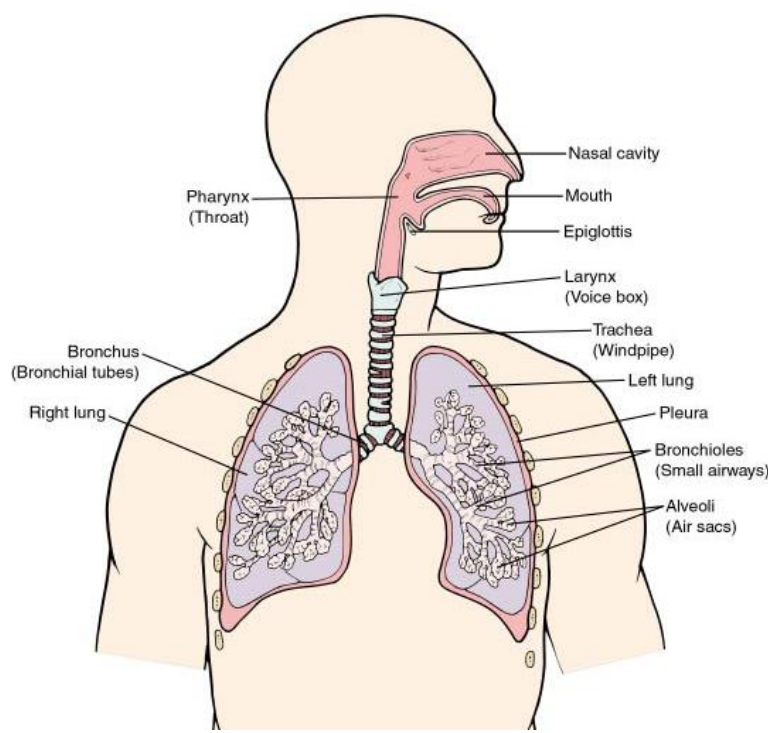

Fig. 1. Anatomy of respiration [15].

The airway starts from the end of the mouth and nose, then to the pharynx, then to the larynx, trachea, bronchus, bronchial tubes, and ends at the alveolocapillary membrane which is the place for air exchange. Between the pharynx and larynx is the base of the tongue which is a frequent occurrence of 
obstruction because the base of the tongue falls backwards causing airway obstruction. Airway obstruction is divided into two namely the total and partial obstruction. Patients who experience total obstruction can be further divided into 2, namely conscious and unconscious. Patients with total obstruction and in a conscious state will look anxious, then a state of cyanosis can be found or not. This is the situation where abdominal thrust can be done. Patients who experience total obstruction with a state of unconsciousness, can cause no symptoms or can only be cyanosis alone. This situation can be done by thoracal thrust. Partial obstruction, you will hear additional voices in victims who have experienced trauma [1,4,18-20].

The airway can be freed by means of multiple maneuvers consisting of the head tilt maneuver, chin lift, jaw thrust, and the triple airway maneuver. All of these methods have the same function of moving the base of the tongue away from the posterior pharynx so that the airway becomes wider. The head tilt, chin lift, jaw thrust, and triple airway maneuvers are maneuvers that can be performed by everyone in dealing with airway disorder and are not definitive treatments. Actions taken to clear the airway can cause or worsen cervical trauma. This risk can be reduced by performing inline immobilization during the maneuver using a neck collar $[1,4,20]$.

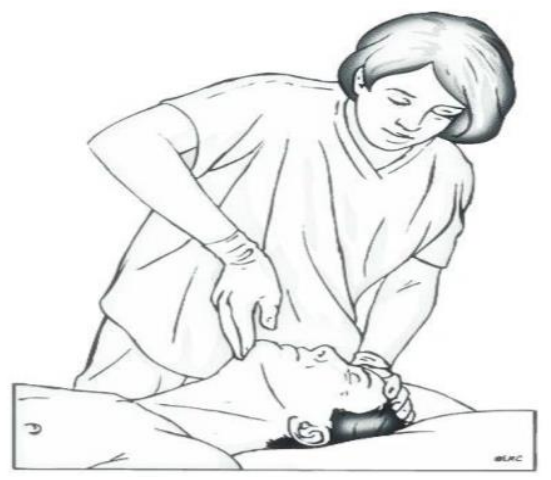

Fig. 2. Head tilt and chin lift [20].

Head tilt and chin lift maneuver as shown in Figure 2 is done by pushing the victim's forehead backwards so that the victim's head is looking up accompanied by lifting the victim's chin. The first thing to do in the head tilt and chin lift maneuvers is to place the middle finger and index finger under the victim's chin. The two fingers lift the chin so that the neck looks more elongated when the head is swung back by the other hand. The head extension raises the chin to pull the tongue and epiglottis up and forward. This condition causes the glottis to open so that the airway becomes better. Emphasis should be focused only on the chin ridge and not the soft tissue of the submandibular region as this can cause obstruction. The final step of the procedure is to use your thumb to open the victim's mouth while the head tilt and chin lift maneuvers are still being carried out. Head tilt and chin lift in cases of trauma are discouraged because they can cause changes in the cervix $[1,4,19,21]$.

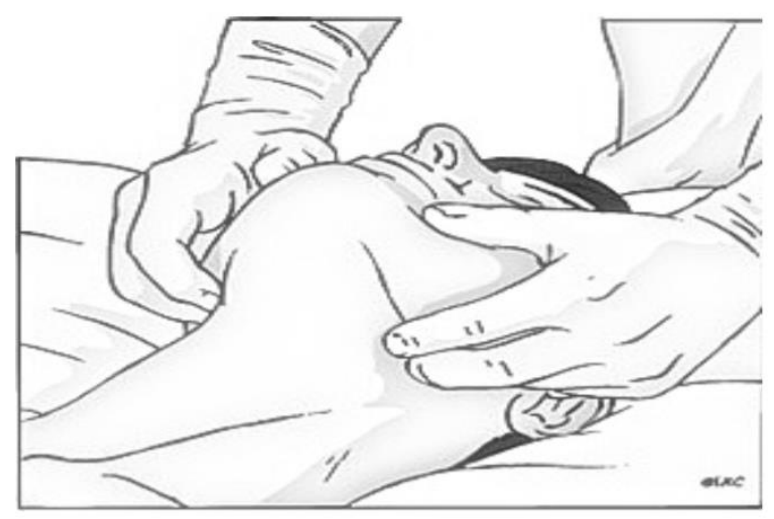

Fig. 3. Jaw thrust [20].

Jaw thrust maneuver is pushing the jaw is done by holding the angle of the mandibular dextra and sinistra steady and push the lower jaw forward. The jaw- thrust maneuver shown in Figure 3 results in neck flexion, extension of the atlantooccipital joint, and mandibular lift so that the base of the tongue is further away from the pharynx and a better airway. The jaw thrust maneuver can be performed in cases of trauma because it does not risk the cervix $[1,4,19]$.

The triple airway maneuver is often cited by some as the beast method of treating airway disorders. The triple airway maneuver is often defined as a combination of head tilt, jaw thrust, and mouth opening. Some other experts interpret the triple airway maneuver differently, namely the combination of upper neck extension, lower neck flexion, and jaw lift. The triple airway maneuver has often been cited as a technique for rescuers who are already adept at dealing with airway disorders $[1,4,19]$.

A neck immobilizer should be attached to all victims who are suspected of having cervical trauma. Victims who have experienced multiple trauma, especially victims with impaired consciousness or trauma above the clavicle region should be suspected of having a cervical fracture, Victims who are accompanied by paralysis, complain of neck pain, or who have neck wounds should also be suspected of having cervical trauma. The helper can carry out manual immobilization if the immobilization tool has to be opened for a while or there is no immobilization tool. Neck extension, flexion, or rotation should not be performed during the process of examining and repairing the airway $[1,4,20,21]$.

Airway clearance can be performed with definitive therapy in certain indications for example in a state of apnea, cyanosis, loss of consciousness as appropriate in Table 1. The endotracheal tube, oropharyngeal tube, and nasopharyngeal tube are tools for definitive therapy. Not all of this therapy can be done, there are certain indications, for example the insertion of a nasopharyngeal tube should not allow facial bleeding because it is suspected that trauma to the cranii base can cause undesirable conditions [4]. 
TABLE I. DEFINITIVE AIRWAY INDICATIONS [4]

\begin{tabular}{|c|c|}
\hline The Need For Airway Protection & The Need For Ventilation \\
\hline Unconscious & Apnea \\
\hline Severe maxillofacial fracture & $\begin{array}{cl}\text { Inadequate respiratory effort } \\
\text { - } & \text { Tachypnea } \\
\text { - } & \text { Hypoxia } \\
\text { - } & \text { Hypercarbia } \\
\text { - } & \text { Cyanosis }\end{array}$ \\
\hline $\begin{array}{cc}\text { Risk of aspiration } \\
\text { - } & \text { Bleeding }\end{array}$ & $\begin{array}{l}\text { Severe head injury } \\
\text { with hyperventilation and } \\
\text { neurological decline }\end{array}$ \\
\hline $\begin{array}{ll}\text { Risk of obstruction } \\
\text { - Hematoma on the neck } \\
\text { - Trauma to the trachea, larynx } \\
\text { - } \quad \text { Stridor }\end{array}$ & \\
\hline
\end{tabular}

2) Breathing and ventilation: Good access does not always guarantee good ventilation. Ventilation is necessary for oxygen exchange and removal of carbon dioxide from the body. Good ventilation includes proper function of the lungs, chest wall, and diaphragm. Each of these components must be evaluated quickly because the disruption can arise from a variety of causes. Thoracic or abdominal trauma will cause impaired movement of the respiratory muscles. Inspection and palpation can reveal chest wall abnormalities that may interfere with ventilation. Disorders of the nervous system that regulate breathing will occur in head trauma, cervical or spinal and related breathing and must be detected during the execution of the primary survey is tension pneumothorax, open pneumothorax, flail chest pulmonary contusion, and massive hemathorax to be addressed at the time in scene [1,4,19-22].

Assessing breathing can also be by look, listen and feel. Look here, you can see the patient's breath movement is symmetrical or not, then to listen, you can see how the patient's vocal breath sounds, and feel the patient with vocal fremitus. Assessment of breathing must be careful because it can cause inadequate oxygen ventilation to the brain or perfusion causing hypoxia [22].

Victims with impaired breathing will show several signs and symptoms such as visible shortness of breath with rapid breathing and appears to be using the additional breathing muscles. Additional breath sounds such as wheezing can be heard. The movements of the right and left hemithorax may be inconsistent or incompatible in some traumas. The respiratory rate can be less than 8 times per minute or more than 30 times per minute. Victims with stopping breathing, no breath sounds, no thoracic or abdominal movements, and victims with gasping are considered to have respiratory problems as well $[1,4,21,22]$.

Ministration if there are respiratory disorders can be a way to give breathing assistance, namely the provision of breath from the mouth (mouth to mouth) in Figure 4, giving breath mouth to nose, giving breath from the mouth to the mask in Figure 5, and giving a breath of mouth to the bag valve mask in Figure 6 [21,22].

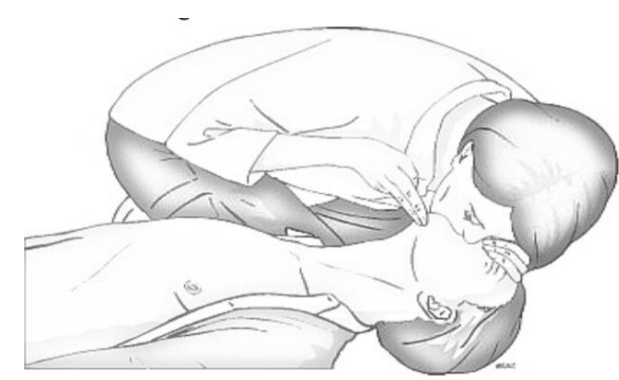

Fig. 4. Giving breath from mouth to mouth [20].

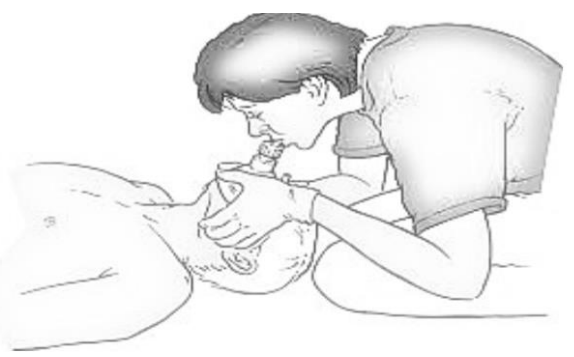

Fig. 5. Exhaling from mouth to mask [20].

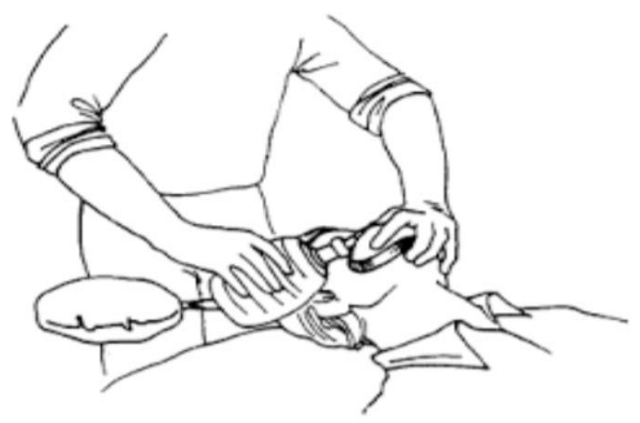

Fig. 6. Giving breath from the mouth to the valve mask bag [20].

3) Circulation with hemorrhage control: Bleeding is a major cause of post-trauma that can be resolved through prompt and appropriate management in the hospital. A trauma victim who is in a hypotensive state should be considered to be in a hypovolemic state and can lead to complications, namely hypovolemic shock until it is proven how the victim's real condition is obtained from a rapid assessment of the victim's hemodynamic status. There are many conditions that can cause hypovolemia and destabilize the hemodynamics of the trauma victim [1,4,19-22].

Hypovolemia is a common problem in trauma patients. Clinical examination that can be done quickly in checking the hemodynamic status of the victim that can be done very quickly, including the level of consciousness, skin color, and pulse will greatly help improve the situation and is an obligation in every aid for trauma victims. A decreased level of consciousness can result from decreased perfusion of blood to the brain due to decreased intravascular blood volume. Victims 
with pale grayish faces and pale skin on their extremities are victims who suffer from hypovolemia. The pulse of hypovolemia victims will be felt fast and small. Pulse examination can be done in a large pulse, for example in the femoral artery or carotid artery with examinations including strength, speed, and pulse rhythm. A large artery pulse or a disappearing heartbeat is a sign to immediately perform cardiac pulmonary resuscitation to improve volume and cardiac output [1,4,21-24].

4) Disability and neurologic status: A quick and brief neurological examination as soon as possible after treatment of life-threatening matters on $\mathrm{ABC}$ should be carried out as soon as possible. Neurological examination of the victim will not be accurate if the hemodynamic condition is not normal. Changes in neurological status from the initial treatment of the victim until the victim's condition stabilizes can indicate damage or improvement. The Glasgow Coma Scale (GCS) assessment is the most important thing to evaluate during this mini neurological examination $[1,4,21,23]$.

Glasgow Coma Scale (GCS) shows the level of brain injury in the victim which will affect the victim's level of consciousness. The GCS calculation is done by adding the eye value to the motor and verbal score of the victim. The highest value is 15 and the lowest value is 3 . Victims with GCS score $13-15$ show the victims were in normal or mild brain injury condition. Victims with a GCS score of 9-12 indicate that the victim is in a state of moderate brain injury. Victims with a GCS value less than equal to 8 indicate that the victim is in a state of serious brain injury $[1,4,21,23]$. Glasgow Coma Scale (GCS) can be seen in Table 2.

TABLE II. GLASGOW COMA SCALE (GCS)

\begin{tabular}{|l|c|}
\hline \multicolumn{1}{|c|}{ Assessment } & Score \\
\hline \multicolumn{1}{|c|}{ Eye } & \\
\hline Opens spontaneously & 4 \\
\hline Opening by verbal stimulation & 3 \\
\hline Opens by pain stimuli & 2 \\
\hline Closed & 1 \\
\hline \multicolumn{1}{|c|}{ ATL } & 6 \\
\hline Keep orders Verbal response & 5 \\
\hline Localized pain & 4 \\
\hline Normal flexion (keeps the limb away from pain stimuli) & 3 \\
\hline & 2 \\
\hline Abnormal extension (decerebration) & 1 \\
\hline No response (flaccid) & 5 \\
\hline Good orientation & 4 \\
\hline Talking chaotic (confused) & 3 \\
\hline Irregular word & 2 \\
\hline Voices and words are not clear & 1 \\
\hline No words & \\
\hline
\end{tabular}

5) Exposure or environment control: All clothes of the victim must be removed so that the general condition of the whole body can be assessed by a log roll. The victim must be kept on guard so as not to experience hypothermia. Victims with hypothermia must be treated quickly so that the victim's body temperature increases or becomes normal [1,4,21,23].

\section{Types of General Practitioner Emergency Training}

The ability and quality of a health personnel will greatly determine the probability of the quality of life of trauma emergency victims. Trauma emergency victims are usually unable to ask for help because of their inability to do so. The speed at which health personnel respond is very important at this time. The more often a general practitioner faces an emergency case, the more prepared he will be to face an emergency case, the one who will suddenly come. Of course, this ability is also inseparable from the emergency training that has been undertaken. There are many types of emergency training available in various fields of emergencies for general practitioners, most commonly called Advanced Trauma Life Support (ATLS), General Emergency Life Support (GEL), Emergency First Aid (PPGD) and others [23-25].

\section{Framework}

Figure 7 shows that the role of general practitioners in hospitals is very important because in Indonesia there is an increase in trauma cases. General practitioners have the competence to handle trauma cases, and general practitioners have been given emergency training. The competencies possessed consist of attitude, skills and knowledge to handle trauma cases. Hopefully, this knowledge competency can reduce mortality due to trauma. Knowledge can be influenced by 2 factors, namely internal and external factors. These internal factors consist of education, experience, and age. External factors consist of economy, environment, information, culture. With this, the researcher wanted to know the level of knowledge of general practitioner in the Polyclinic and Emergency room at Dustira Hospital on the primary survey in trauma cases.

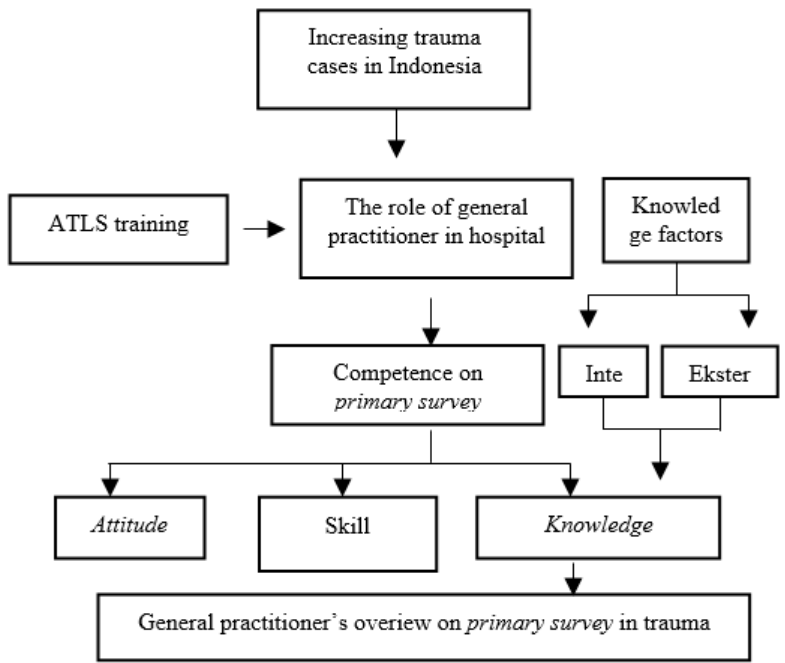

Fig. 7. Framework. 


\section{RESEARCH MATERIALS AND METHODS}

\section{A. Research Design}

The research was conducted using a descriptive observational method. Researchers made observations about the level of knowledge of general practitioner at Dustira Hospital on the primary survey.

\section{B. Sample Size}

Sampling in this study used descriptive categorical because the results of the study will be grouped based on classification, namely good, moderate, poor. From the calculation, the minimum sample size was 62 people. Sample size calculations are attached in appendix 5 .

\section{Research Variables}

The variables in this study were primary survey knowledge, history of emergency training, age, and length of work.

\section{Research Procedures}

1) Preparation

- Determine the research field and submit a research theme proposal to the academic department of the Faculty of Medicine, Universitas Jenderal Achmad Yani.

- Conducting a literature review and consultation with supervisors in determining the research theme.

- Design research proposals and questionnaires.

- Test the validity of the questionnaire content to 2 Advanced Trauma Life Support (ATLS) instructors to determine the suitability of the contents of the questionnaire with ATLS science.

- To test the reliability of the questionnaire as a statistical basis in the preparation of research instruments.

2) Data collection

- Make data collection permits through the education installation of the Dustira Hospital

- Confirmation to the medical committee of Dustira Hospital about the number of samples and work shifts for data collection

- Collecting data through a questionnaire to the respondents, namely as many as 41 general practitioners.

3) Research instruments: The research instrument used was a questionnaire containing 28 questions with a reference to the Advanced Trauma Life Support book for general practitioners. The twenty-eight questions consist of 6 questions regarding airway, 6 questions regarding breathing, 6 questions regarding circulation, 5 questions regarding disability, and 5 questions regarding exposure. The research questionnaire also includes the application sheet and the consent form to be the research respondent.

The research instrument has been tested for validity and reliability before being tested so that the questionnaire is valid and has good consistency. The expert review test with this specification begins with validating the contents of the questionnaire through 2 ATLS instructors. The results of the content validity test that have been corrected by the ATLS instructor are as follows (Table 3):

TABLE III. VALIDATION OF CONTENT

\begin{tabular}{|l|l|l|}
\hline \multicolumn{1}{|c|}{ Expert } & \multicolumn{1}{|c|}{$\begin{array}{c}\text { Question } \\
\text { number }\end{array}$} & \multicolumn{1}{c|}{ Input expert reviews } \\
\hline $\begin{array}{l}\text { General } \\
\text { Surgeon }\end{array}$ & Number 6 & $\begin{array}{l}\text { For oxygen saturation is normally } \\
90 \% \text { N } \\
\text { The longer the duration of the } \\
\text { breath assistance is given, } \\
\text { the breathing gets better }\end{array}$ \\
\hline Neurosurgeons & Number 24 4 & $\begin{array}{l}\text { Resuscitation with ringer's lactate } \\
\text { that is not warm }\end{array}$ \\
\hline & $\begin{array}{l}\text { Only jaw thrust maneuvers are } \\
\text { permitted } \\
\text { Thoracosynthetic needle }\end{array}$ \\
\hline
\end{tabular}

The results of the reliability test were some unreliable questions because there were questions that had no variation because the answers were the same for all respondents so that the result was 0.33. Questions that are less reliable are replaced.

4) How to measure the level of knowledge: The questionnaire contains 28 questions and consist of 6 airway questions, 6 breathing questions, 6 circulation questions, 5 disability questions, and 5 exposure questions. Respondents are welcome to provide 'wrong' or 'correct' responses to each question. The assessment of the respondent's correct answer to a question was given score of ' 1 ' on the initial 25 questions and questions with multiple choice were given a score of ' 2 ' while the wrong assessment was given a score of ' 0 '.

After calculating the total score, it is determined that the level of knowledge is good, sufficient, and insufficient. Interpretation is carried out on each respondent's answer and then a comprehensive data analysis is carried out.

\section{E. Data Analysis}

The data that has been collected from the results of filling out the questionnaire was analyzed. Univariable data analysis includes age, length of work, training followed and knowledge. The results of the descriptive data analysis will be presented in tabular and narrative form, furthermore, statistical data analysis is carried out to determine the characteristics and level of general practitioner knowledge about the primary survey with components airway, breathing, circulation, disability, and exposure using one of the statistical applications. 


\section{F. Place and Time of Research}

The research was conducted at the Dustira Hospital and the Unjani Faculty of Medicine from January 2016 to February 2017.

\section{RESULTS AND DISCUSSION}

\section{A. Characteristics of Respondents}

Characteristics of respondents were divided by length of work and experience in emergency training are included in the data category and analyzed using tables.

1) Age of respondents: Respondents consisted of various ages. Respondent age data were processed using the central tendency and can be seen in Table 4 .

TABLE IV. CHARACTERISTICS OF RESPONDENTS BASED ON AGE AT DUSTIRA HOSPITAL, DECEMBER 2016 TO JANUARY 2017

\begin{tabular}{|c|c|}
\hline Age Range (years) & Frequency \\
\hline $26-30$ & 24 \\
\hline $31-35$ & 5 \\
\hline $36-40$ & 4 \\
\hline $41-45$ & 1 \\
\hline $46-50$ & 2 \\
\hline$\geq 51$ & 3 \\
\hline Total & 39 respondents \\
\hline
\end{tabular}

Table 4 shows that the respondents in the age range 2630 were 24 respondents and the youngest age was 26 years and the most were 27 years old. The age range of 31-35 years was 5 respondents. There were 4 respondents in the age range of 36-40 years. The age range of $41-45$ years is 1 respondent. The age range of 46-50 years was 2 respondents, and the age range of more than 51 years was 3 respondents, and the oldest age of the respondents was 55 years old. Knowledge is related to age, namely the younger the individual's age, the higher the ability to remember the information received, while the older the individual, the more changes in body physiology will reduce the ability to remember the information received [26].

2) Length of employment of respondents: All respondents have worked as a general practitioner at the Dustira Hospital. Old working data is processed using a statistical application and can be seen in Table 5 .

TABLE V. CHARACTERISTIC RESPONDENTS BASED ON LENGTH OF EMPLOYMENT IN DUSTIRA HOSPITAL

\begin{tabular}{|c|c|c|}
\hline Length of working & Frequency & Percentage (\%) \\
\hline$<1$ year & 8 & 20.5 \\
\hline $1-10$ & 26 & 66.7 \\
\hline $11-20$ & 3 & 7.7 \\
\hline $21-30$ & 2 & 5.1 \\
\hline Total & 39 respondents & 100 \\
\hline
\end{tabular}

The length of work referred to in this section is the length of time the respondent has worked as a general practitioner at the Dustira Level II Hospital. Table 5 shows that there were 8 respondents who had worked for less than 1 year, but there were also respondents who had worked for 344 months ( 29 years). The length of work ranged from 1 to 10 years as many as 26 respondents. The average length of work of the respondents was 55.72 months (4.6 years) with a range of different lengths of service for respondents who were registered as Civil Servants (PNS) and honorary staff. According to Notoadmojo [12], knowledge is related to experience, which can be from the length of time someone has worked. The more often people do something, the more experience they will be eating [15].

3) Respondents' emergency training experience: Experience in emergency training certainly has a very big role in influencing respondents' knowledge of the primary survey. As the experience of a general practitioner increases, the general practitioner's knowledge should also increase about his own health, patient health, the ability to analyse general practitioner information, and perform general practitioner actions $[27,28]$.

TABLE VI. DISTRIBUTION OF RESPONDENT CHARACTERISTICS BASED ON EMERGENCY TRAINING AT THE DUSTIRA HOSPITAL $($ NUMBER = 39)

\begin{tabular}{|c|c|c|}
\hline Characteristics & Number of respondents & Percentage (\%) \\
\hline Never attended training & 5 & 13 \\
\hline Have attended training & 34 & 87 \\
\hline
\end{tabular}

Respondents have the same formal educational background, but not all respondents have the same training education. All respondents were expected to have the ability in the introduction and processing of the primary survey. This is because most of the respondents, namely $87 \%$, have attended emergency training and only 5 respondents have never attended any training. Details of the respondent's emergency training can be seen in Table 6 which contains the types of training that have been carried out by the respondent.

TABLE VII. DISTRIBUTION OF RESPONDENT CHARACTERISTICS BASED ON THE TYPE OF EMERGENCY TRAINING AT DUSTIRA HOSPITAL (NUMBER = 34)

\begin{tabular}{|l|c|c|}
\hline Emergency training & Number of respondents & Percentage (\%) \\
\hline ATLS & 20 & 59 \\
\hline NON - ATLS & 14 & 41 \\
\hline TOTAL & 34 & 100 \\
\hline
\end{tabular}

It can be seen in Table 7, 20 respondents (59\%) have attended Advanced Trauma Life Support (ATLS) training and other training, 14 respondents $(41 \%)$ did not attend ATLS training or these respondents attended other training. In the future general practitioners who attend ATLS training could have better knowledge of the primary survey compared with no training.

\section{B. Respondents' Knowledge Level}

The level of knowledge of respondents regarding the primary survey in this study was divided into six sub variables, 
namely the primary survey in general, airway, breathing, circulation, disability, and exposure. All measurements of the level of knowledge are divided into three categories, namely good knowledge, sufficient knowledge, and insufficient knowledge.

1) Level of knowledge regarding the primary survey in general: Table 8 shows the percentage of respondents in the three categories of knowledge levels regarding the primary survey in general.

TABLE VIII. DISTRIBUTION OF RESPONDENTS BASED ON THE LEVEL OF KNOWLEDGE ABOUT THE PRIMARY SURVEY IN GENERAL AT THE DUSTIRA HOSPITAL (NUMBER $=39$ PEOPLE)

\begin{tabular}{|l|c|c|}
\hline Knowledge level & Number of respondents & Percentage (\%) \\
\hline Good & 20 & 51 \\
\hline Enough & 18 & 46 \\
\hline Less & 1 & 3 \\
\hline
\end{tabular}

A part $(51 \%)$ of the total 20 respondents had knowledge both on primary survey, 18 respondents $(46 \%)$ are knowledgeable enough about the primary survey, and 1 respondent $(3 \%)$ had less knowledge on primary survey. The results of data analysis in Table 8 show that the distribution of respondents varies for each level of knowledge and is dominant by the category of good knowledge.

TABLE IX DISTRIBUTION OF RESPONDENTS BASED ON THE LEVEL OF KNOWLEDGE ABOUT THE PRIMARY SURVEY ON RESPONDENTS WHO TOOK ATLS IN GENERAL AT THE DUSTIRA LEVEL II HOSPITAL (NUMBER = 20)

\begin{tabular}{|c|c|c|}
\hline Knowledge level & Number of respondents & Percentage (\%) \\
\hline Good & 8 & 40 \\
\hline Enough & 12 & 60 \\
\hline Less & 0 & 0 \\
\hline
\end{tabular}

Table 9 shows the primary survey knowledge level of 8 respondents (40\%) who had a good level of knowledge and 12 respondents (60) who had sufficient knowledge.

TABLE $X$. DISTRIBUTION OF RESPONDENTS BASED ON THE LEVEL OF KNOWLEDGE ABOUT THE PRIMARY SURVEY ON RESPONDENTS WHO DID NOT TAKE ATLS (FOLLOWING OTHER TRAINING) IN GENERAL AT DUSTIRA HOSPITAL (TOTAL $=14)$

\begin{tabular}{|l|c|c|}
\hline Knowledge level & Number of respondents & Percentage (\%) \\
\hline Good & 10 & 72 \\
\hline Enough & 3 & 21 \\
\hline Less & 1 & 7 \\
\hline
\end{tabular}

Table 10 shows an overview of the primary survey knowledge level of 10 respondents $(72 \%)$ who had a good level of knowledge, 3 respondents $(21 \%)$ who had a sufficient level of knowledge and 1 respondent $(7 \%)$ who had a less level of knowledge.

The results showed that the level of knowledge who did not follow the ATLS was better than those who took the ATLS because there were doctors who attended the ATLS but had not used their knowledge for a long time because they had not worked in the emergency department for a long time and there were doctors who did not follow the ATLS but worked in the emergency department so that experience affects the level of knowledge. Work experience affects the level of knowledge because the more knowledge he applies, the more his level of knowledge increases [12].

TABLE XI. DISTRIBUTION OF RESPONDENTS BASED ON THE LEVEL OF KNOWLEDGE ABOUT THE PRIMARY SURVEY AMONG RESPONDENTS WHO DID NOT PARTICIPATE IN GENERAL EMERGENCY TRAINING AT THE DUSTIRA LEVEL II HOSPITAL (NUMBER $=5$ )

\begin{tabular}{|l|c|c|}
\hline Knowledge level & Number of respondents & Percentage (\%) \\
\hline Good & 2 & 40 \\
\hline Enough & 2 & 40 \\
\hline less & 1 & 20 \\
\hline
\end{tabular}

Table 11 shows the primary survey knowledge level of 2 respondents who did not attend emergency training $(40 \%)$ had a good level of knowledge. those who had enough level of knowledge were also $40 \%$ as the level of knowledge of good, and one of the respondents $(20 \%)$ who has less level of knowledge.

These percentages are expected by many general practitioners with good knowledge in the primary survey on trauma cases because this knowledge should have been obtained when they received education and emergency training, although not only education and training but experience also has an effect [29]. The world's recognized training is ATLS. Many Indonesian doctors have participated in this training, around more than 1 million doctors in 50 countries. It is hoped that emergency training doctors can prevent an increase in mortality, but not only doctors are responsible, but nurses also have an important role in handling trauma victims [4].

These percentages are not in line with Hutapea research that studies the level of knowledge of traffic police in Depok on primary survey [30]. Hutapea showed that $50 \%$ of research respondents actually head less knowledge about the primary survey, this was because there were differences in experience between respondents in this study were people who repeatedly studied the primary survey, while Hutapea respondents were ordinary people, not all of whom had studied the primary survey [11,30]. The results of this study are in line with Kusumawati's research which shows that many nurses in the perinatology room of RSAB Harapan Bunda have good knowledge about the primary survey [31]. Kusumawati and Hutape research cannot be compared with this study because there are differences in the characteristics of respondents, but both of these studies demonstrate that the level of knowledge in accordance with the competence gained from formal education which led the respondent to apply their competency. In this study, $51 \%$ of respondents had good knowledge of the primary survey. Previous studies, the level of knowledge of nurses in the ER Dustira Hospital in 2014 showed that 50\% of respondents on nurses of the emergency department had 
less knowledge on airway and breathing. This study cannot be compared with previous studies because of different subjects, but previous research can describe the level of knowledge of nurses and this study can describe the level of knowledge of general practitioners. Knowledge about the primary survey really needs to be considered because with this knowledge it can save emergency victims, if the knowledge of medical personnel at the Dustira Hospital is lacking, it can endanger the safety of the victims [11].

2) Level of knowledge regarding airway: Knowledge of the airway is the knowledge of a general practitioner in assessing or managing the airway. Airway abnormality will cause death faster than breathing abnormality, so that the airway becomes the first priority in the primary survey and determines the success of handling the next primary survey steps. The level of knowledge of respondents about the airway can be seen in Table 12 .

TABLE XII. DISTRIBUTION OF RESPONDENTS BASED ON THE LEVEL OF KNOWLEDGE ABOUT THE AIRWAY DUSTIRA HOSPITAL (NUMBER=39)

\begin{tabular}{|l|l|l|}
\hline \multicolumn{1}{|c|}{ Knowledge level } & Number of respondents & Percentage (\%) \\
\hline Good & 11 & 27 \\
\hline Enough & 22 & 55 \\
\hline Less & 7 & 18 \\
\hline
\end{tabular}

The level of knowledge of respondents about the airway is in line with the level of knowledge about the primary survey in general. Table 12 shows that half of the total population, namely 11 respondents $(27 \%)$ have good knowledge, 22 respondents $(55 \%)$ have sufficient knowledge, and only 7 respondents (18\%) have insufficient knowledge. Based on this, it can be assumed descriptively that the airway is likely to be one of the parts that the respondents do not understand in assessing and managing the primary survey.

3) Level of knowledge regarding breathing: Measurement of the respondent's level of knowledge about breathing is the respondent's knowledge of important things in assessing and managing the breathing process of trauma emergency victims. Abnormalities in the breathing process will cause death faster than hemodynamic abnormalities so that breathing becomes the second priority after airway and before circulation [4]. The results of data management on the level of respondent's knowledge about breathing can be seen in Table 13.

TABLE XIII. DISTRIBUTION OF RESPONDENTS BASED ON THE LEVEL OF KNOWLEDGE ABOUT BREATHING IN THE DUSTIRA HOSPITAL (NUMBER = 39)

\begin{tabular}{|l|c|c|}
\hline Knowledge level & Number of respondents & Percentage (\%) \\
\hline Good & 5 & 13 \\
\hline Enough & 18 & 46 \\
\hline less & 16 & 47 \\
\hline
\end{tabular}

Breathing, like airway, can descriptively be assumed to be a difficult part of the primary survey. Based on Table 13 showed that half the total population (13\%) namely 5 respondents had good knowledge about breathing, 18 respondents (46\%) had knowledge enough about breathing, and only 16 respondents (41\%) who have less knowledge about the breathing.

Comparison of the percentage level of respondents' knowledge about breathing and airway which shows almost the same results because airway management cannot be separated from the management of breathing because these two things are related to the airway and the breathing process [4].

4) Level of knowledge regarding circulation: Measurement of the respondent's level of knowledge regarding circulation in the primary survey, which is aimed at measuring the respondent's knowledge of research and management of the hemodynamics of trauma emergency victims so that shock does not occur and maintaining fluid perfusion into the tissue in an adequate state [12]. The assessment and management of circulation on the primary survey is the third priority and is carried out after the airway and breathing $[1,12]$. The results of data management on the level of knowledge of general practitioners regarding circulation can be seen in Table 14 .

TABLE XIV. DISTRIBUTION OF RESPONDENTS BASED ON THE LEVEL OF KNOWLEDGE ABOUT CIRCULATION IN THE DUSTIRA HOSPITAL (NUMBER = 39)

\begin{tabular}{|l|c|c|}
\hline Knowledge level & Number of respondents & Percentage (\%) \\
\hline Good & 19 & 49 \\
\hline Enough & 17 & 43 \\
\hline Less & 3 & 8 \\
\hline
\end{tabular}

Table 14 shows that $49 \%$, namely 19 respondents, have good knowledge about circulation, $43 \%$, i.e. 17 respondents have sufficient knowledge about circulation, and 3 respondents $(8 \%)$ have insufficient knowledge.

5) Level of knowledge regarding disability: Assessment of disability in the primary survey leads to rapid neurological examination. This rapid neurological examination uses the Glasgow Coma Scale *GCS) benchmark, which is a simple scoring system and can predict outcomes after handling airway, breathing and circulation and is commonly used to determine the degree of head injury $[1,12]$. The respondent knowledge about disability fallow is also the level of knowledge about the Glasgow Coma Scale and can be seen in Table 15.

TABLE XV. DISTRIBUTION OF RESPONDENTS BASED ON THE LEVEL OF KNOWLEDGE ABOUT DISABILITY IN THE DUSTIRA HOSPITAL $($ NUMBER $=39$ )

\begin{tabular}{|l|c|c|}
\hline \multicolumn{1}{|c|}{ Knowledge level } & Number of respondents & Percentage (\%) \\
\hline Good & 36 & 92 \\
\hline Enough & 1 & 3 \\
\hline Less & 2 & 5 \\
\hline
\end{tabular}


Respondents' knowledge of disabilities or GCS assessment can be assumed to be good. Table 15 shows the majority of the 36 respondents $(92 \%)$ have a good knowledge about disability, one respondent (3\%) had knowledge enough, and 2 respondent (5\%) had knowledge about the disability.

6) Level of knowledge regarding exposure: Measurement of respondent's knowledge of exposure is a measure of the respondent's knowledge of the importance of removing the clothes of a victim of trauma to see if there is any disability in various regions of the body accompanied by efforts to prevent the victim from entering into a hypovolemic state which can have bad consequences. ${ }^{4}$ The results of measuring the level of knowledge regarding exposure can be seen in Table 16.

TABLE XVI. DISTRIBUTION OF RESPONDENTS BASED ON THE LEVEL OF KNOWLEDGE ABOUT EXPOSURE IN THE DUSTIRA HOSPITAL (NUMBER $=39$ )

\begin{tabular}{|l|c|c|}
\hline Knowledge level & Number of respondents & Percentage (\%) \\
\hline Good & 34 & 87 \\
\hline Enough & 4 & 10 \\
\hline less & 1 & 3 \\
\hline
\end{tabular}

Respondents' knowledge about exposure in the primary survey can be assumed to be good. This can be seen in Table 16 which shows that more than half of the respondents, namely 34 respondents $(87 \%)$ have good knowledge about exposure, 4 respondents $(10 \%)$ have sufficient knowledge, and 1 respondent $(3 \%)$ have less knowledge about exposure. Based on these results descriptively it can be assessed that most respondents already understand exposure in the primary survey, but some respondents do not understand it.

\section{RESULTS AND CONCLUSION}

From the results of this study, it can be concluded as follows:

- As much as $51 \%$ of general practitioners at Dustira Hospital have less knowledge about primary survey, especially on airways and breathing.

- Respondents who took ATLS by $40 \%$ had a good level of knowledge.

- Respondents who did not take ATLS by $72 \%$ had a good level of knowledge.

- Respondents who did not attend the training by $40 \%$ have a good level of knowledge.

\section{REFERENCES}

[1] S. Sjamsuhidayat, Buku Ajar Ilmu Bedah, Edisi ke-3. Jakarta: EGC, 2010 .

[2] J.H. Creel, Scene size up. In: Campbell, J.E. Basic trauma life support for paramedics and other advanced providers. 4th ed. New Jersey: Alabama Chapter American Collage of Emergency Physicians. 2000, p. $1-22$.
[3] WHO, Status Keselamatan Jalan di WHO Regional Asia Tenggara tahun 2013. India: Word Health Organization, 2013.

[4] American College of Surgeons Committee on Trauma, ATLS student course manual, ed. 8. Jakarta: Komisi trauma ikatan ahli bedah Indonesia, 2008

[5] U. Enggarsasi and N.K. Sa'diyah, "Kajian terhadap faktor-faktor penyebab kecelakaan lalu lintas dalam upaya perbaikan pencegahan kecelakaan lalu lintas," Perspektif, vol. 22, pp. 238-247, 2017.

[6] S. Djaja, R. Widyastuti, K. Tobing, D. Lasut, and J. Irianto, "Gambaran kecelakaan lalu lintas di Indonesia Tahun 2010-2014,” Jurnal Ekologi Kesehatan, vol. 15, pp. 30-42, 2016.

[7] D. Wicaksono, R.A. Fathurochman, B. Riyanto, and Y.I. Wicaksono, "Analisis Kecelakaan Lalu Lintas (Studi Kasus-Jalan Raya UngaranBawen)," Jurnal Karya Teknik Sipil, vol. 3, pp. 345-355, 2014.

[8] P.C. Zai, A. Wagiu, and R. Rawung, "Profil Pasien Trauma akibat Kecelakaan Lalu Lintas yang Dirawat di Instalasi Rawat Darurat Bedah RSUP Prof. Dr. RD Kandou Manado Periode 1 Januari-31 Desember 2017," e-CliniC, vol. 6, 2018.

[9] M.E. Bolla, "Kajian Karakteristik Kecelakaan Sepeda Motor Di Kota Surabaya," Jurnal Teknik Sipil, vol. 1, pp. 67-79, 2011.

[10] Departemen Kesehatan Replubik Indonesia, Peraturan Menteri Kesehatan replubik Indonesia No. 340/Menkes/Per/III/2010 tentang klasifikasi rumah sakit. Jakarta: Depkes RI, 2010.

[11] I. Falah, Gambaran Tingkat Pengetahuan Perawat Instalasi Gawat Darurat Rumah Sakit Dustira Tentang Primary Survey Kasus Trauma: Fakultas Kedokteran Universitas Jenderal Achmad Yani. Cimahi: Universitas Jenderal Achmad Yani, 2014.

[12] S. Notoatmodjo, Promosi kesehatan dan ilmu perilaku. Jakarta: Rineka Cipta, 2005, p. 140-142

[13] A. Wawan and M. Dewi, Teori dan pengukuran pengetahuan, sikap, dan perilaku manusia. Yogyakarta: Nugraha Medika, 2010

[14] S.T. Siboro, Hubungan kondisi kerja dan karakteristik individual dengan stress kerja pada pegawai lembaga pemasyarakatan kelas IIB Lubuk Pakam 2008,2009. Medan: USU Respiratory, 2009.

[15] H. Malayu, Manajemen sumber daya manusia, edisi revisi. Jakarta: Bumi Aksara, 2005

[16] N.A. Kishk, "Knowledge, attitudes, and practice of women toward antenatal care: rural-urban comparison," J Egypt Public Health Assoc., vol. 77, pp. 479-98, 2002.

[17] F. Effendi and M. Makhfudli, Keperawatan kesehatan komunitas. Edisi ke-1. Jakarta: Salemba Medika, 2009, p. 101-103.

[18] N.J. Smelser, "Psychological trauma and cultural trauma," Cultural trauma and collective identity, vol. 4, pp. 31-59, 2004.

[19] P.A. Potter, and A.G. Perry, Fundamental of nursing. 6th ed. Carolina: Mosby Year Book Inc, 2004.

[20] K.L. Moore and A.F. Dalley, Anatomi berorientasi klinisi jilid 3. 5th ed. Jakarta: Erlangga, 2013

[21] R.M. Bell and B.E. Krantz, Intial assessment. 2000. In: mattox, K.L., Feliciano, D.V., Moore, E.E. Trauma. 4th ed. New York San Francisco Bogota Caracas Lisbon Madrid Mexico City New Delhi San Juan Singaproe Sidney Toronto: The McGraw Hill Companies Inc. P154.

[22] J. Soar, J.P. Nolan, B.W. Böttiger, G.D. Perkins, C. Lott, P. Carli, and N.I. Nikolaou, "European resuscitation council guidelines for resuscitation 2015: section 3. Adult advanced life support," Resuscitation, vol. 95, pp. 100-147, 2015.

[23] E. Papdi, Kegawatdaruratan Penyakit Dalam (Emergency in internal medicine). Jakarta: Interna Publishing, 2012.

[24] A. Mansjoer, Pengkajian Awal Kegawatdaruratan Medis 2014. Ilmu Penyakit Dalam. Edisi III. Jakarta: Interna publishing.

[25] S. Sudiharto, Buku panduan bsic trauma cardiac life support. Jakarta: Sagung Seto, 2013, p. 26-40

[26] W. Wayunah, E. Nurachman, and S. Mulyono, Hubungan pengetahuan perawat tentang terapi infus dengan kerjadian plebitis dan kenyamanan 
pasien di ruang rawat inak RSUD Kabupaten Indramayu. Depok: Fakultas Ilmu Keperawatan Universitas Indonesia, 2011.

[27] A. Aryani, Analisis pengetahuan dan motivasi perawat yang mempengruhi sikap mendukung penerapan progam patient safety. Yogyakarta: Universitas Diponegoro. 2009.

[28] E. Ngalngola, A. Maidin, and S.A. Pasinringi, "Gambaran Pengetahuan Dan Motivasi Perawat Terhadap Penerapan Program Patient Safety Di Instalasi Rawat Inap RSUD Daya Makassar Tahun 2012," Jurnal Ners, vol. 7, pp. 23-29, 2012.
[29] P.R.G.N. Lee, "trauma training: a literature review." Emergency Nurse Journal, vol. 15, pp. 30-31, 2007.

[30] E.L. Hutapea, Gambaran TingkatPengetahuan Polisi Lalu Lintas Tentang Bantuan Hidup Dasar (BHD) Di kota Depok. Skripsi. Jakarta: Fakultas Ilmu Keperawatan Universitas Indonesia, 2012.

[31] N.N. Kusumawati, Gambaran tingkat pengetahuan perawat tentang perawatan metode Kanguru di RSAB Harapan kita. Depok: Univesitas Indonesia, 2011. 